\title{
39. THE ACCRETIONARY PRISM OF THE NANKAI TROUGH OFF SHIKOKU, SOUTHWESTERN JAPAN ${ }^{1}$
}

\author{
Hideo Kagami, Ocean Research Institute, University of Tokyo ${ }^{2}$
}

\begin{abstract}
The accretionary prism of the Nankai Trough off Shikoku Island is divided into four tectonic zones, based chiefly upon the characteristics of thrust faults and the velocity distribution within the wedge. They are, from trough axis to Tosa Terrace: the protothrust zone, imbricate thrust zone, multiple décollement zone, and earthquake thrust zone.

The stacking velocity of the nondeformed trench-fill turbidites is $1.7 \mathrm{~km} / \mathrm{s}$. After accretion it gradually increases to $4.0 \mathrm{~km} / \mathrm{s}$ or higher in the earthquake thrust zone. This value represents the critical geophysical boundary between the elastic deformation in the earthquake thrust zone and the aseismic deformation in the multiple décollement, imbricate thrust, and protothrust zones. Within the outer margin of the Tosa Terrace, the earthquake thrusts extend to the surface from this boundary, raising the outer margin at a rate of 70 to $200 \mathrm{~cm}$ every $120 \mathrm{yr}$. Thus, sediment accretion in the Nankai wedge is controlled by development of these thrusts.

Two subzones within the imbricate thrust zone and two types of décollements are recognized within the zones of aseismic deformation. The western subzone of the imbricate thrust zone is represented by imbricate thrusts with vertical displacement up to $1000 \mathrm{~m}$. The eastern subzone is characterized by a duplex thrust or an imbricate thrust without vertical displacement, which probably caused great historical earthquakes because of the effective horizontal movement of the thrust. Primary décollements develop in the protothrust and imbricate thrust zones, and multiple décollements develop only in the multiple décollement zone. The primary décollement is made by an overburden of trench-fill sediments that creates high pore-water pressure within the Shikoku Basin hemipelagite with porosity between 30 and $50 \%$. The multiple décollement may be formed by the secondary dewatering, which is related to dissolution or diagenesis of sediments in the $20 \%$ porosity range.
\end{abstract}

\section{INTRODUCTION}

This report describes the development of the accretionary prism along the Nankai Trough off Shikoku Island, based chiefly upon the characteristics of thrust faults and the velocity distribution seen in already published multichannel seismic lines (Aoki et al., 1982; Nasu et al., 1982; Tamano et al., 1983) and single-channel air-gun data provided by the $\mathrm{Hydrographic}$ Office of $\mathrm{Ja}$ pan. Additional multichannel lines taken by the Ocean Research Institute are discussed by Kagami and others (1985). Original concepts published in Japanese (Kagami et al., 1983) concerning the development of the accretionary prism are modified slightly here.

The terminology for features within this setting is rather confusing, but this report follows the vocabulary of Moore and others (1982) and Boyer and Elliott (1982). Much of the emphasis attached to the protothrust zone resulted from discussions with D. Karig on board the Glomar Challenger during the Leg 87 cruise.

Convergent plate boundaries can represent sites of crustal growth and are characterized by great earthquakes, intense deformation of sediments, and extraordinary topographic relief. The operative process could be similar to those of mountain belts (Bally and Snelson, 1980), although the process of accretionary tectonics at convergent boundaries is a much younger and shorter process.

\footnotetext{
${ }^{1}$ Kagami, H., Karig, D. E., Coulbourn, W. T., et al., Init. Repts. DSDP, 87: Washing. ton (U.S. Govt. Printing Office).

2 Address: Ocean Research Institute, University of Tokyo 1-15-1 Minamidai, Nakano, Tokyo 164, Japan.
}

\section{DESCRIPTION OF SINGLE-CHANNEL AIR-GUN DATA}

The observed area off Shikoku can be divided into four areas according to variations of the accretionary prism.

\section{The Eastern Area between Tosabae and Shionomisaki Peninsula}

As shown in a single-channel air-gun profile of Line 38 (Figs. 1 and 2), the protothrust zone is not well developed in the floor of the trough. The first imbricate thrust block has a height of 200 to $500 \mathrm{~m}$ and is relatively broad $(8 \mathrm{~km})$. A major thrust bounds this imbricate zone on the north. The topography seen between 3 and $4 \mathrm{~s}$ two-way traveltime is complicated by many peaks (Fig. 2). This setting is where the Nankaido earthquake thrust occurred in 1946. The Minami Tosabae, a broad sediment-covered ridge, lies at about $2 \mathrm{~s}$ two-way traveltime. A sediment-filled trough separates Minami Tosabae and Tosabae, which is located further northward (Line 45-56 in Fig. 3). The northern border of the filled trough is thought to be another major seismic thrust, the result of the 1854 Ansei earthquake.

A piston-core sample taken from the trough floor near Shionomisaki Canyon recovered sandy turbidites (Kagami, 1975).

\section{Transitional Area off Muroto Peninsula}

Line N55-1 crosses the middle of the boundary area between Shionomisaki and the transitional area off Muroto Peninsula where the strike of surface and subsurface 


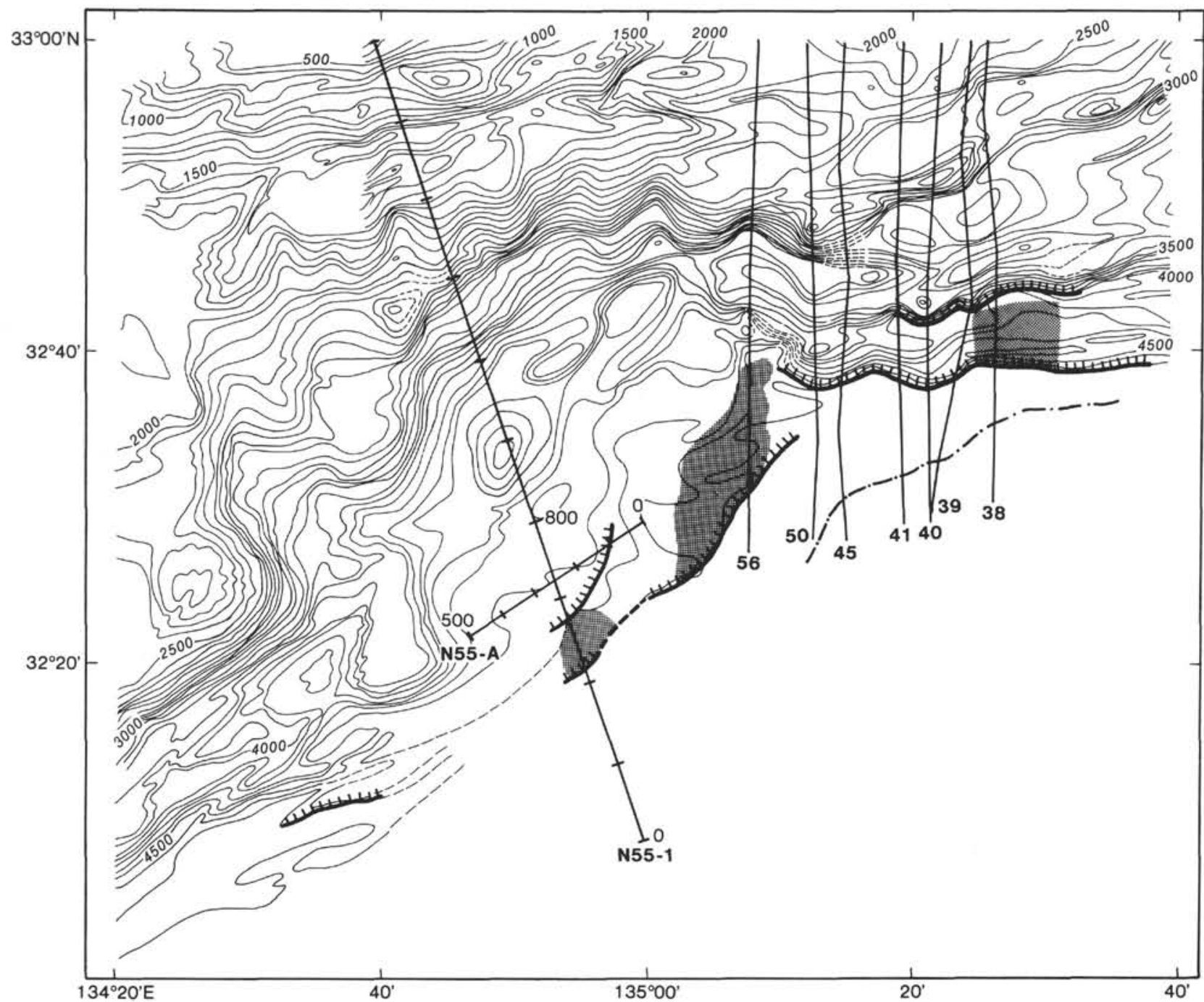

Figure 1.Bathymetry and location of seismic reflection lines $(38,39,40,41,45,50,56$, N55-1) in the eastern area between Tosabae and Shionomisaki Peninsula. Contour interval, $100 \mathrm{~m}$. Shaded area represents plateaulike imbricate thrust block. Dot-dash line is deformation front and dashed lines are uncertain depth contours.

structures swings from northeast to north-northeast, perpendicular to the vector for the Philippine Sea plate motion. A broad imbricate thrust zone, composed of many semi-horizontal thrusts or duplex thrusts, characterizes this profile (Fig. 4). The well-developed protothrust zone includes an area with box folds, $100-200 \mathrm{~m}$ high and $5 \mathrm{~km}$ wide (Lines 4 and 7 in Figs. 5 and 6).

Submarine topographic contours indicate a basement high in the seaward of this area (Line 1 in Fig. 6). At Line 4 , sediment isopachs reveal a graben in the ocean basement where the trench-fill sediments are $500 \mathrm{~m}$ thick. The basement high could dam the trench-fill sediments adjacent to the continental margin.

\section{The Area off Ashizuri Peninsula}

This area is characterized by regular development of an imbricate thrust zone for more than $100 \mathrm{~km}$ along strike. The most seaward imbricate block is clearly recognized in Lines 14,15 , and 17 (Fig. 7). The $3.5-\mathrm{kHz}$ record along N55-3-1 shows an imbricate block with a plateau-like shape and the protothrust zone as rolling hills grading seaward onto a through floor. The first imbricate thrust is located between the plateau and the hills (Fig. 8). Sites 582 and 583 were drilled in this area.

\section{The Western Area off Hyuga, Kyushu}

The strike of the axis of the Nankai Trough becomes more nearly north-south in this area (Fig. 9), and the filled sediments in the trough thin toward the south-southwest where the trough finally ends bounded by the Kyushu-Palau Ridge. Imbricate thrust blocks are well developed, and the imbricate slices are rotated landwards.

Because seismic profiles show less stratification in the trench-fill sediments, and also because they thin toward the south-southwest, we assume that the trench-fill sediment itself becomes muddy (Fig. 10). This fining is partly shown by a piston-core sample taken by the Geological Survey of Japan (Site 368 of GSJ); the samples consist mostly of homogeneous greenish gray clayey mud with a very few sand laminae (Inoue, 1978). 


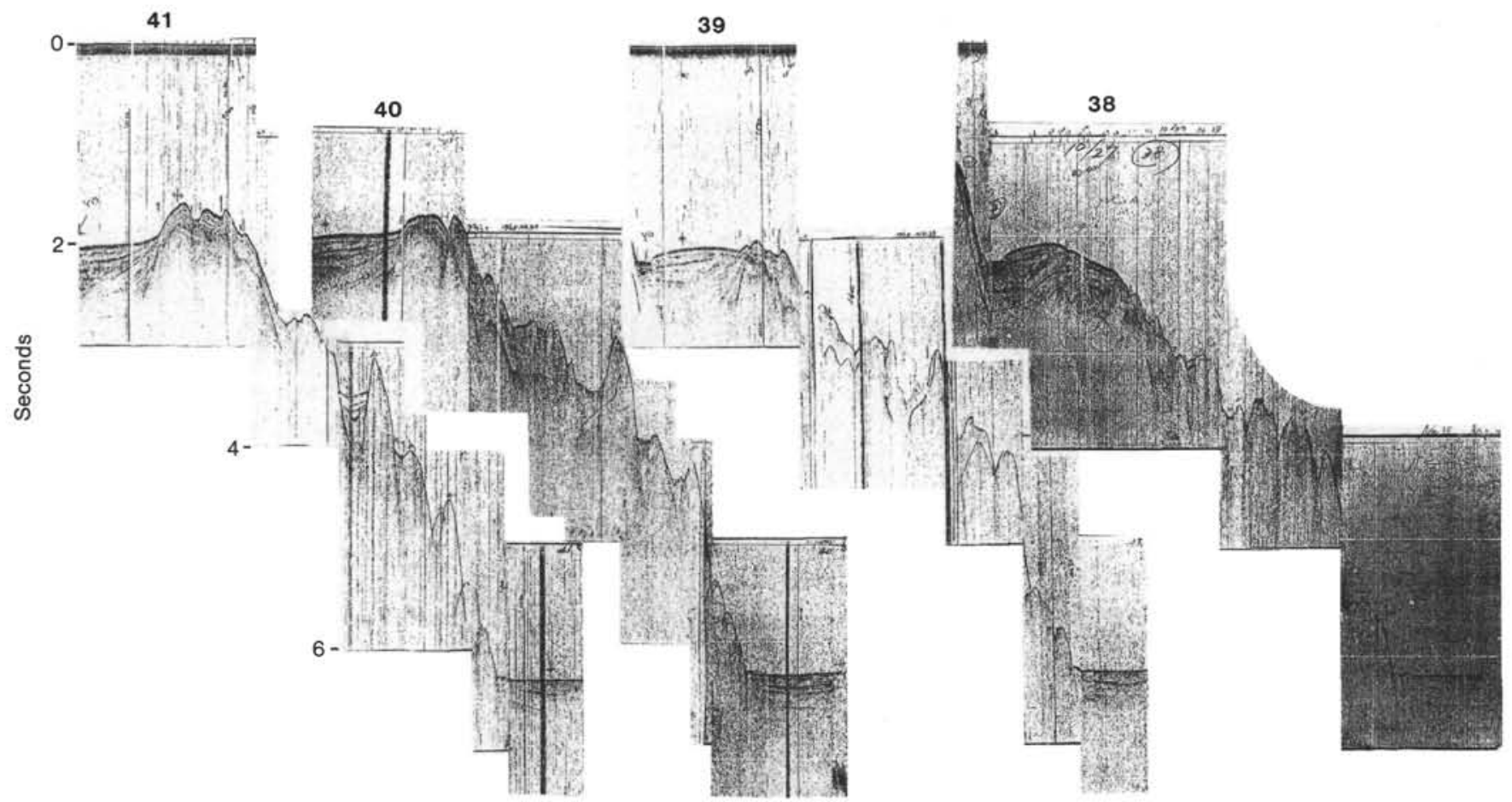

Figure 2. Single-channel air-gun Profiles 38 to 41 in the eastern area between Tosabae and Shionomisaki Peninsula. Locations of profiles in Figure 1.
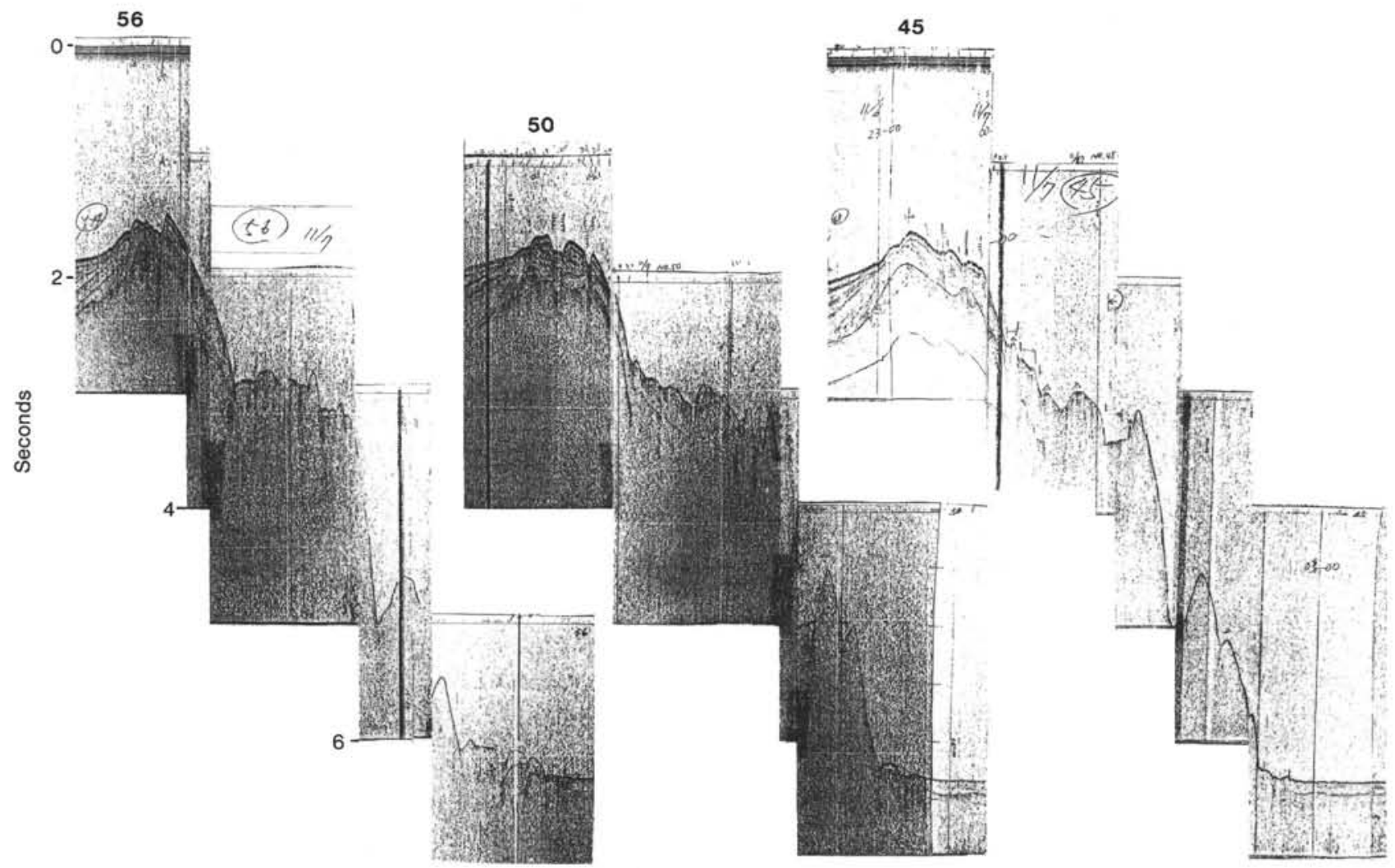

Figure 3. Single-channel air-gun Profiles 45, 50, and 56 in the eastern area between Tosabae and Shionomisaki Peninsula. Locations of profiles in Figure 1. 


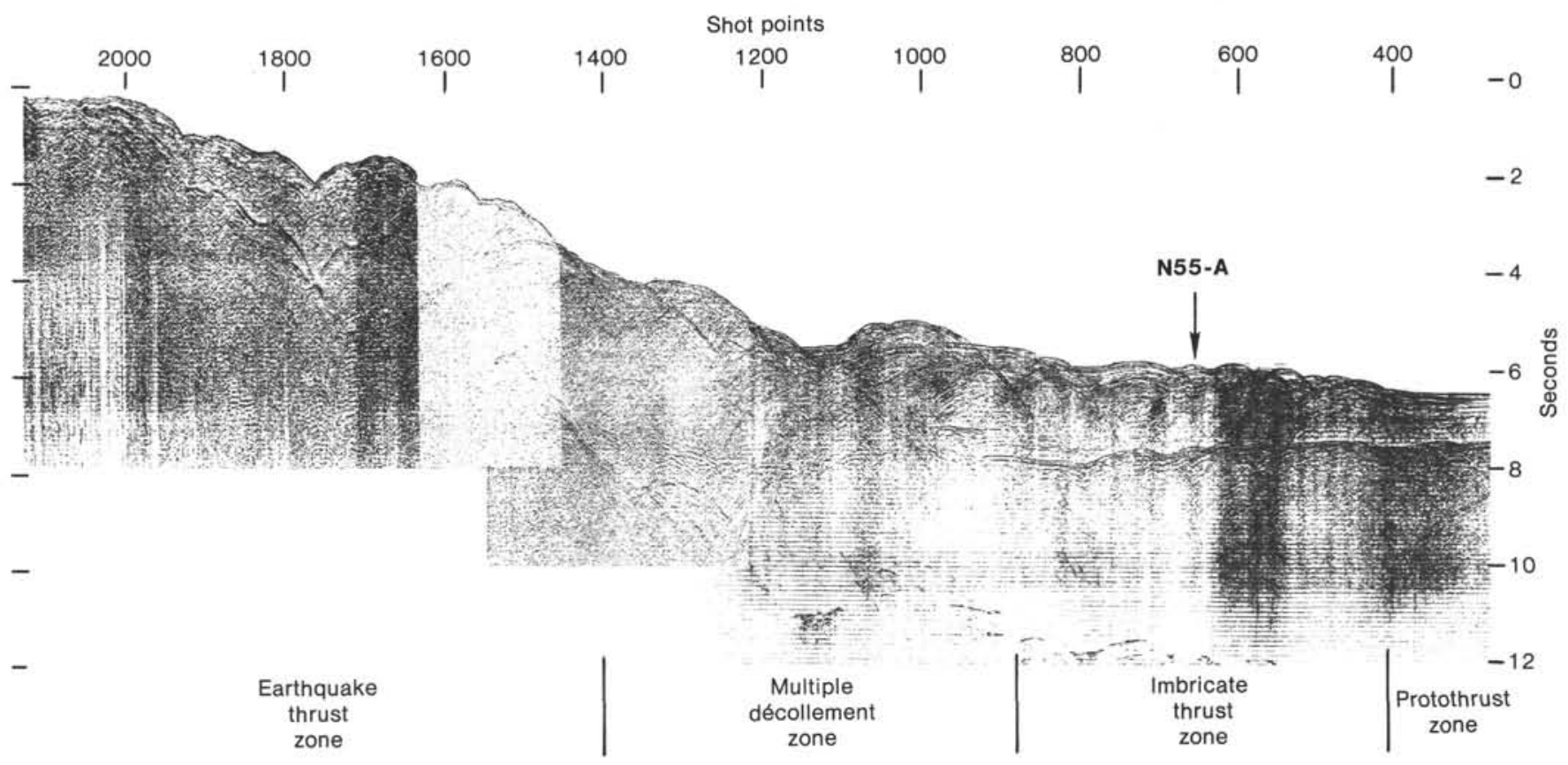

Figure 4. Four tectonic zones on multichannel Profile N55-1.

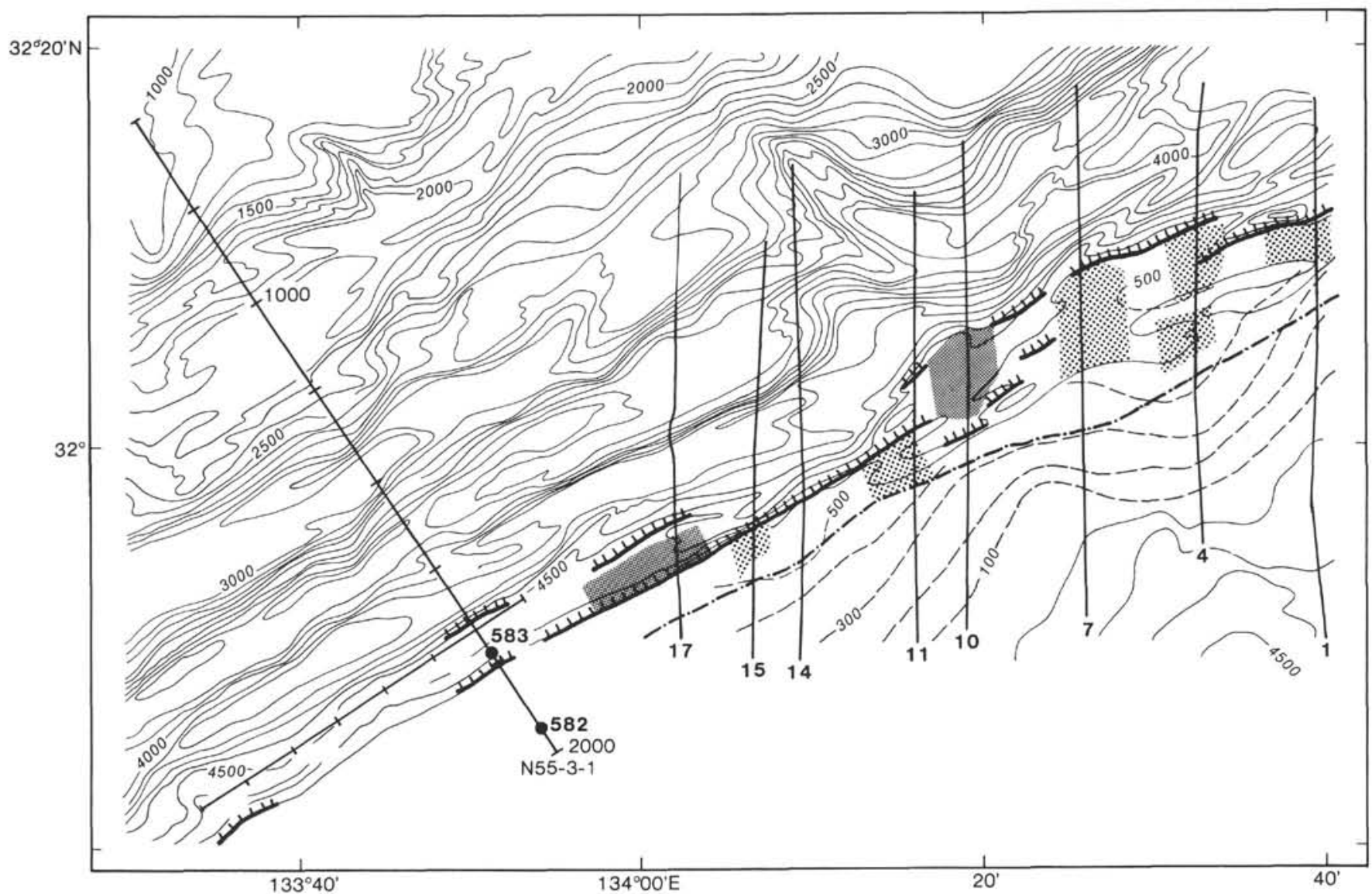

Figure 5. Bathymetry and location of seismic reflection lines $(1,4,7,10,11,14,15,17$, N55-3-1) in the transitional area off Muroto Peninsula. Contour interval, $100 \mathrm{~m}$. Shaded area represents plateaulike imbricate thrust block, and dotted area represents box folds. Dot-dash line is deformation front and dashed lines are isopachs of the trench-fill turbidites. 


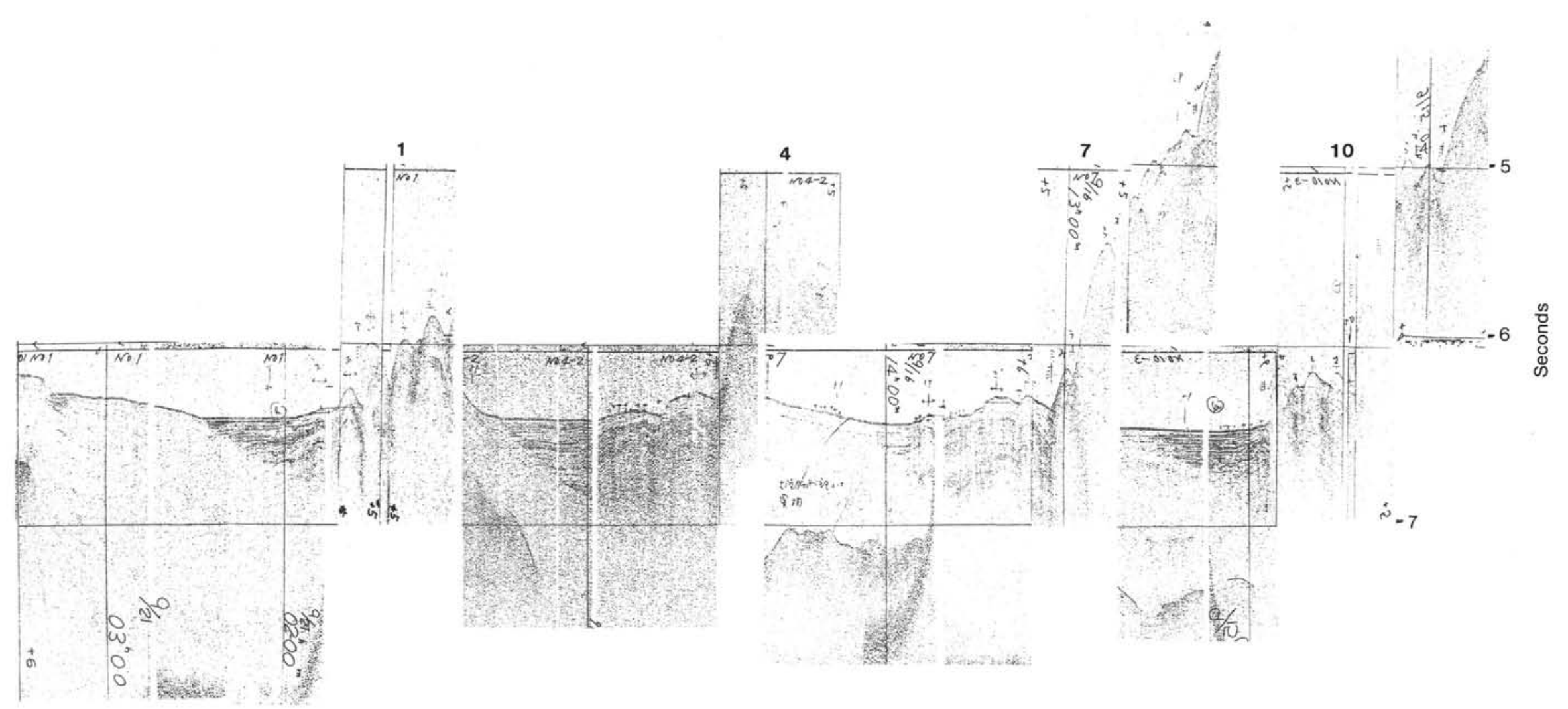

Figure 6. Single-channel air-gun Profiles 1, 4, 7, and 10 in the transitional area off Muroto Peninsula. Locations of profiles in Figure 5. 


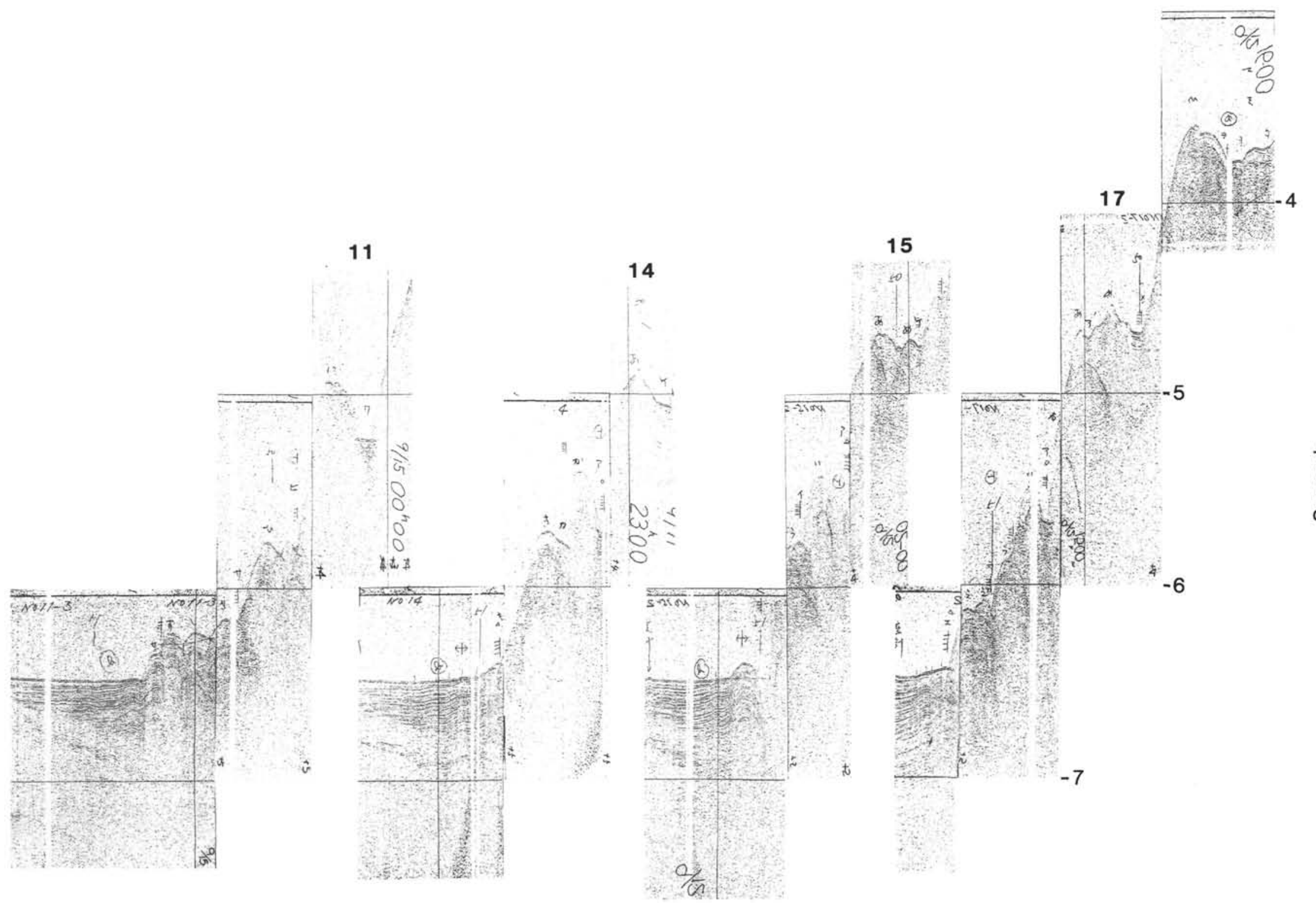

Figure 7. Single-channel air-gun Profiles 11, 14, 15, and 17 in the transitional area off Muroto Peninsula. Locations of profiles in Figure 5. 


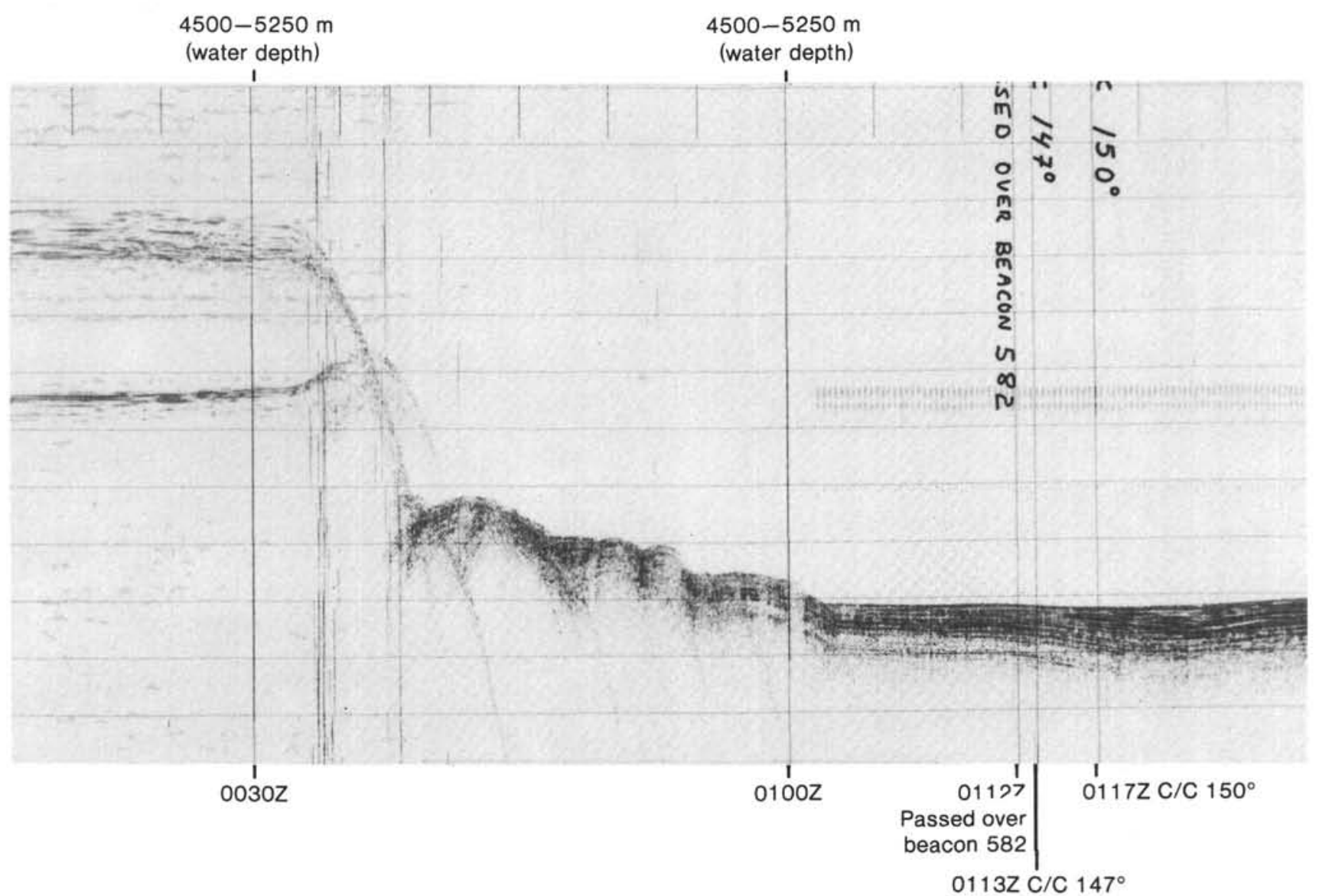

Figure 8. Glomar Challenger 3.5-kHz profile taken along the multichannel Profile N55-3-1 during Leg 87. For location of N55-3-1, see Figure 5. $\mathrm{C} / \mathrm{C}=$ course change.

\section{TYPES OF THRUSTS OBSERVED IN THE ACCRETIONARY PRISM}

The seaward-most zone of the accretionary prism starts near the axis of the trough and gradually rises landward until it abuts the first cliff created by a thrust (Fig. 4). This protothrust zone is thickened partly by box folds, but on a small scale it is thickened by high-angle thrusts at approximately $60^{\circ}$ to the horizontal (Kagami et al., 1982). Fissile kink-partings recovered at $382 \mathrm{~m}$ sub-bottom at Hole 583F, located on the edge of the imbricate thrust zone, are perhaps correlative with these $60^{\circ}$ thrusts in the protothrust zone (site chapter, Site 583 , this volume).

The second zone starts from the thrust scarp at about $4600 \mathrm{~m}$ depth to the middle of the slope at about $4000 \mathrm{~m}$ where the prism becomes very thick. This zone is characterized by imbricate thrusts dipping landward at 30 to $40^{\circ}$ and by the development of a basal décollement. We will refer to this décollement as the primary décollement. The imbricate thrust zone is divided into eastern and western subzones. The eastern subzone roughly coincides with the eastern and transitional areas mentioned already and is characterized by duplex thrusts and imbricate thrusts lacking rotation of imbricate slices (Profiles 55-1 and 55-4 in Fig. 11). Profile 55-4 represents a typical duplex thrust without a primary décollement. Hori- zontal displacements are probably compensated for by duplex thrusting alone. In contrast, the western subzone has imbricate blocks, $5 \mathrm{~km}$ wide and $2 \mathrm{~km}$ thick, and bedding planes are rotated to about $40^{\circ}$, especially in the landward slices (Profile 55-7 in Fig. 11). This subzone represents a typical imbricate thrust with vertical displacement of about $1000 \mathrm{~m}$.

The third zone begins from the place where a great change in slope gradients occurs and ends at the outer cliff of the Tosa Terrace at a depth of about $2000 \mathrm{~m}$. Sometimes this zone is thrust-bounded at both sides. A canyon at shot point (SP) 1330 in Line N55-3-1 causes an acoustic lens, and the horizontal reflectors beneath 5 to $7 \mathrm{~s}$ in two-way traveltime may represent multiple décollements (Fig. 12), which are also observed on other profiles (Fig. 11). The multiple décollements are not simple continuations of the primary décollement, but rather may shift their position to the higher level because of the great friction between the ocean crust and the overlying accreted sediments.

The fourth zone lies on the outer uplifted portion of the Tosa accretionary basin, where post-Shimanto formations such as $\mathrm{K}$ series and $\mathrm{T}$ formation of Okuda (1984) outcrop on a seafloor devoid of slope sediments. The area has been classified as a $T_{2}$ active fault zone by the Research Group For Active Faults In Japan (1980). The Nankaido earthquake in 1946 and the Ansei earth- 


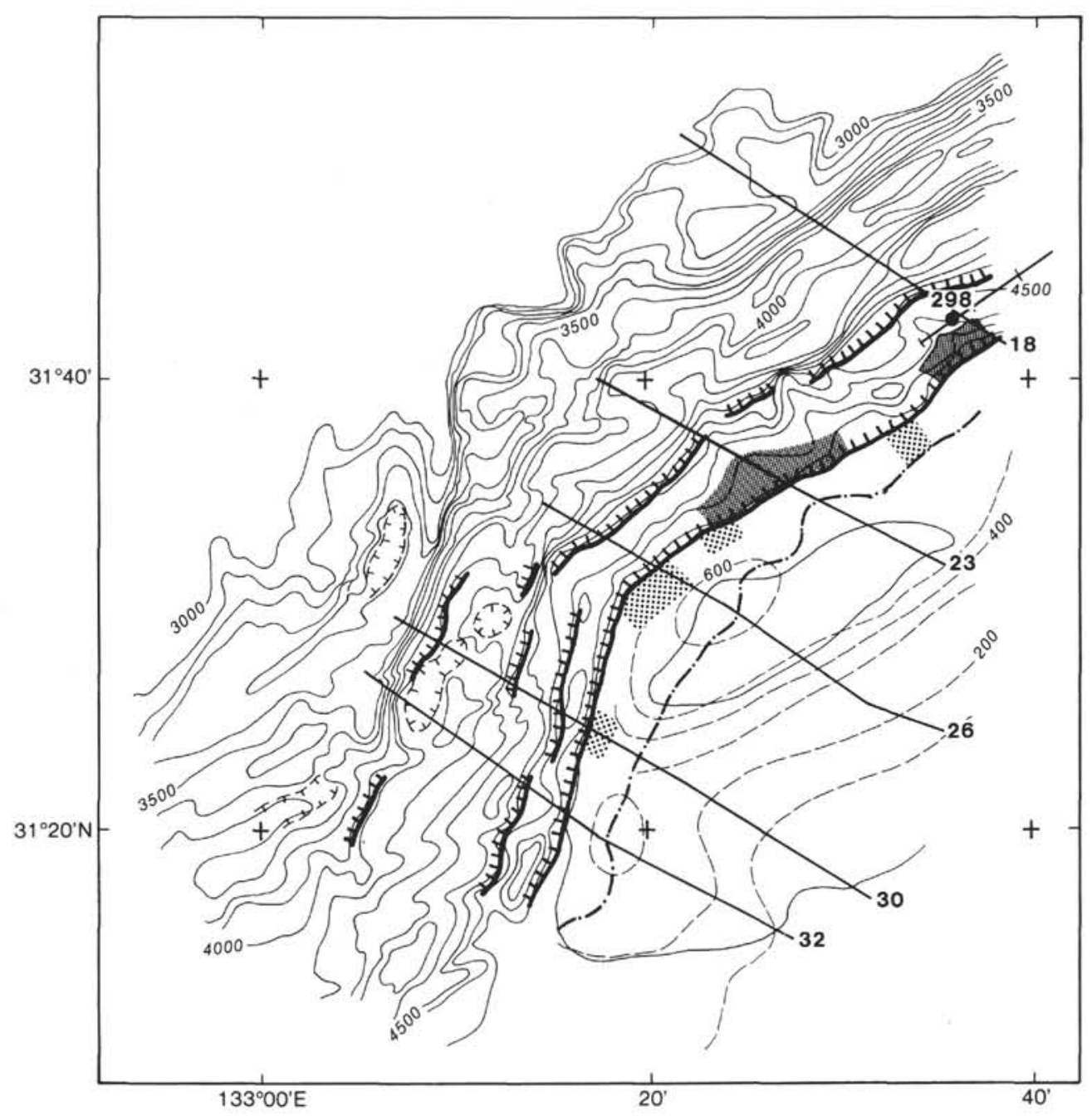

Figure 9. Bathymetry and location of seismic reflection lines $(18,23,26,30,32)$ in the western area off Hyuga, Kyushu. Contour interval, $100 \mathrm{~m}$. Shaded area represents plateaulike imbricate thrust block, and dotted area represents box folds. Dot-dash line marks deformation front and dashed lines are isopachs of the trench-fill turbidites.

quake in 1854 occurred in this zone. One of the seismic thrusts is identified on the profile (Figs. 12 and 13) and has dip angles of 10 to $15^{\circ}$. Because it dips under Shiko$\mathrm{ku}$ Island at almost the same angle as the Wadachi-Benioff plane, this seismic thrust is considered the main fault plane between the Philippine Sea and the Eurasian plate boundaries.

\section{VELOCITY DISTRIBUTION IN THE ACCRETIONARY PRISM}

From the stacking velocity distribution, we can divide the accretionary wedge into four zones (Fig. 12). A refraction seismic study carried out in this area shows almost the same velocity structure (Yoshii et al., 1973). The boundaries of the four zones lie at shot points 1820 , 1430 , and 1070 (Fig. 12). In the protothrust zone, velocities range between 1.7 to $2.4 \mathrm{~km} / \mathrm{s}$. This zone is composed of a two-storied structure, an upper trench-fill turbidite and a lower hemipelagic mud. Velocities of the upper turbidite range from 1.7 to $2.1 \mathrm{~km} / \mathrm{s}$ and those of the hemipelagic mud from 2.1 to $2.4 \mathrm{~km} / \mathrm{s}$. The detailed velocity structure of this zone is represented in a synthetic seismograph (Aoki et al., this volume).

In the imbricate thrust zone, velocities range from 1.9 to $3.2 \mathrm{~km} / \mathrm{s}$. The variation within this zone is very small, indicating homogeneity within this portion of the prism. This zone also composed of a two-storied structure; the upper horizon is a deformed trench-fill turbidite mixed partly with slope sediments, and the lower horizon is a hemipelagic mudstone and Pliocene-Miocene turbidite. Velocities of the upper horizon range from 1.9 to $2.4 \mathrm{~km} / \mathrm{s}$ and the lower horizon from 2.5 to 3.2 $\mathrm{km} / \mathrm{s}$. A velocity of $2.5 \mathrm{~km} / \mathrm{s}$ generally indicates transition from unconsolidated to consolidated sediments.

The third zone comprises a three-storied section between SP 1070 and 1430. The upper horizon is approximately $500 \mathrm{~m}$ thick and ranges from 1.6 to $2.1 \mathrm{~km} / \mathrm{s}$ in velocity, probably representative of slope sediments. The middle horizon is $2 \mathrm{~km}$ thick with velocities ranging from 2.7 to $3.4 \mathrm{~km} / \mathrm{s}$. Its constituents may be consolidated trench-fill turbidites. The lower horizon is 2 to $3 \mathrm{~km}$ thick, has velocities ranging from 3.5 to $3.9 \mathrm{~km} / \mathrm{s}$, and is prob- 


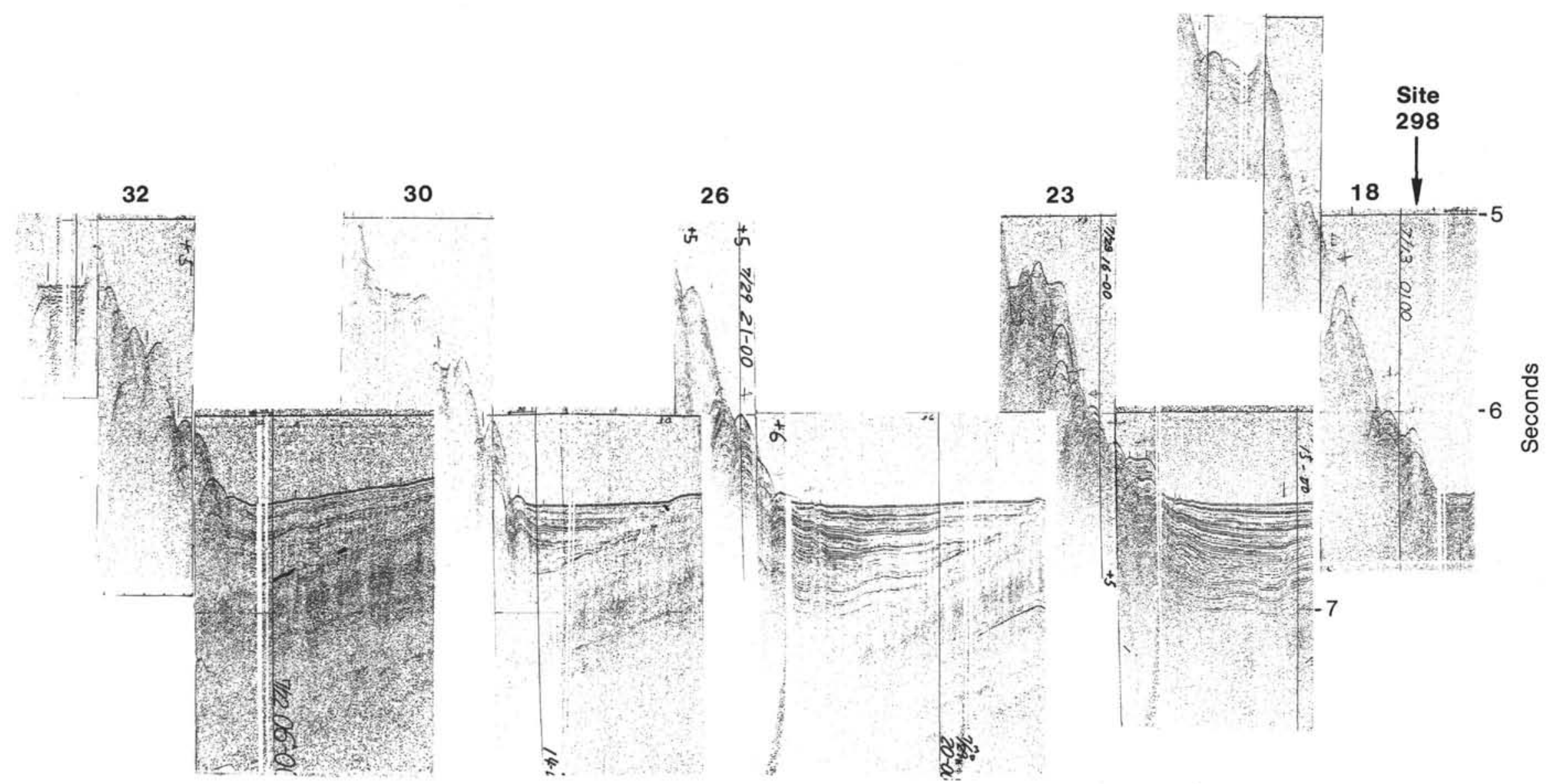

Figure 10. Single-channel air-gun Profiles 18, 23, 26, 30, and 32 in the western area off Hyuga, Kyushu. Locations of profiles in Figure.9. 

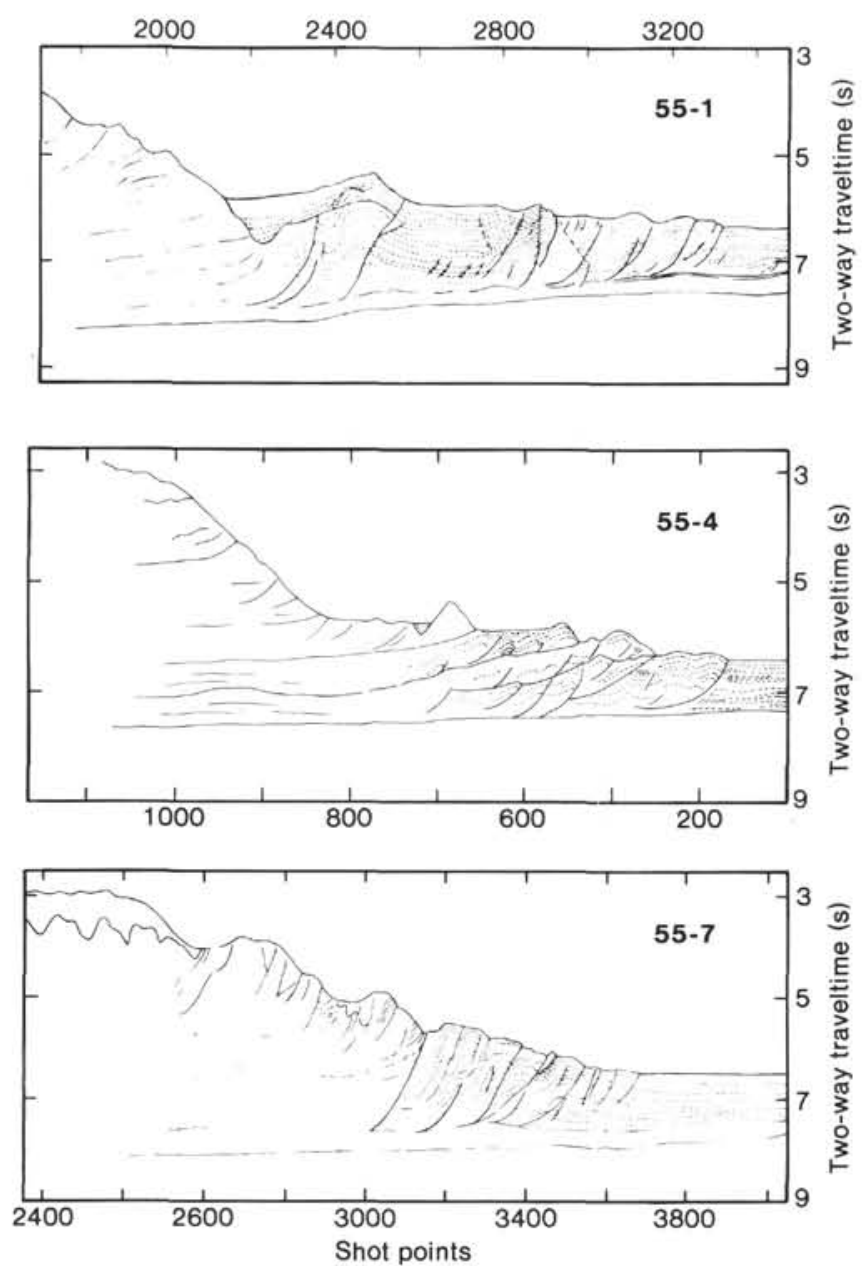

Figure 11. Sketch of multichannel seismic Sections 55-1, 55-4, and 55-7. Horizontal scale of shot points are plotted at distances of $50 \mathrm{~m}$ each. Locations of sections in Figure 14.

ably composed of hemipelagic mudstones and lower Pliocene-Miocene turbidites. The upper trench-fill turbidites are also incorporated within this horizon, because multiple décollements function to carry sediments landward.

The fourth zone is characterized by a low-angle seismic thrust developing beneath the outer margin of the
Tosa Terrace where the forearc basin has evolved since the middle Miocene (Okuda, 1984). Absence of slope sediments having velocities between 1.7 and $2.5 \mathrm{~km} / \mathrm{s}$ may indicate continuous uplift along the outer margin of the Tosa Terrace. This zone is composed of three horizons. The upper horizon, $2.6-2.9 \mathrm{~km} / \mathrm{s}$, represents the $\mathrm{K}$ and $\mathrm{T}$ formations. A middle horizon with velocities of 3.7 to $3.8 \mathrm{~km} / \mathrm{s}$ is $1 \mathrm{~km}$ thick and is not clearly linked either to accreted sediments or to the Shimanto Formation by seismic stratigraphy. The lower horizon is $5 \mathrm{~km}$ thick, and velocities range from 4.0 to $4.9 \mathrm{~km} / \mathrm{s}$. This horizon is probably made of accreted sediments, because its thickness corresponds to that of Horizons 2 and 3 in Zone 3 and its velocity of 4.0 to $4.9 \mathrm{~km} / \mathrm{s}$ reflects a gradual increase from 3.5 to $3.9 \mathrm{~km} / \mathrm{s}$ in Zone 3 .

\section{DISCUSSION AND CONCLUSION}

Four tectonic zones are identified according to the nature of thrusts and acoustic properties of the Nankai accretionary wedge (Table 1; Fig. 14).

The first zone is the protothrust zone, where the seafloor shoals at a gradient of 2 to $3^{\circ}$ from the trough axis, but in a board sense is still within the trough floor. The boundary from the undeformed trough floor, which might be called a deformation front, is transitional and not easily recognized. Within this zone deeper hemipelagic mud thickens by ductile deformation where an incipient primary décollement is developing, and the upper trench-fill turbidites are offset by a swarm of highangle thrusts at an angle of $60^{\circ}$. Box folds occur at the transitional area sporadically and are the major structure in this zone. The acoustic velocity of this zone is 1.7 to $2.1 \mathrm{~km} / \mathrm{s}$, not much different from the nondeformed trench-fill turbidites. We do not see this zone in the Japan Trench, perhaps because it can only develop at places where thick trench-fill turbidites overlie pelagic sediments.

The second zone is called the imbricate thrust zone. In the typical case, it consists of a train of imbricate blocks with a width of 3 to $5 \mathrm{~km}$. Boundaries between the blocks are landward-dipping reflectors (thrusts) with angles of 30 to $40^{\circ}$. In most cases, the seaward imbricate blocks are simply uplifted without rotation along the thrusts. Landward blocks are gradually rotated along

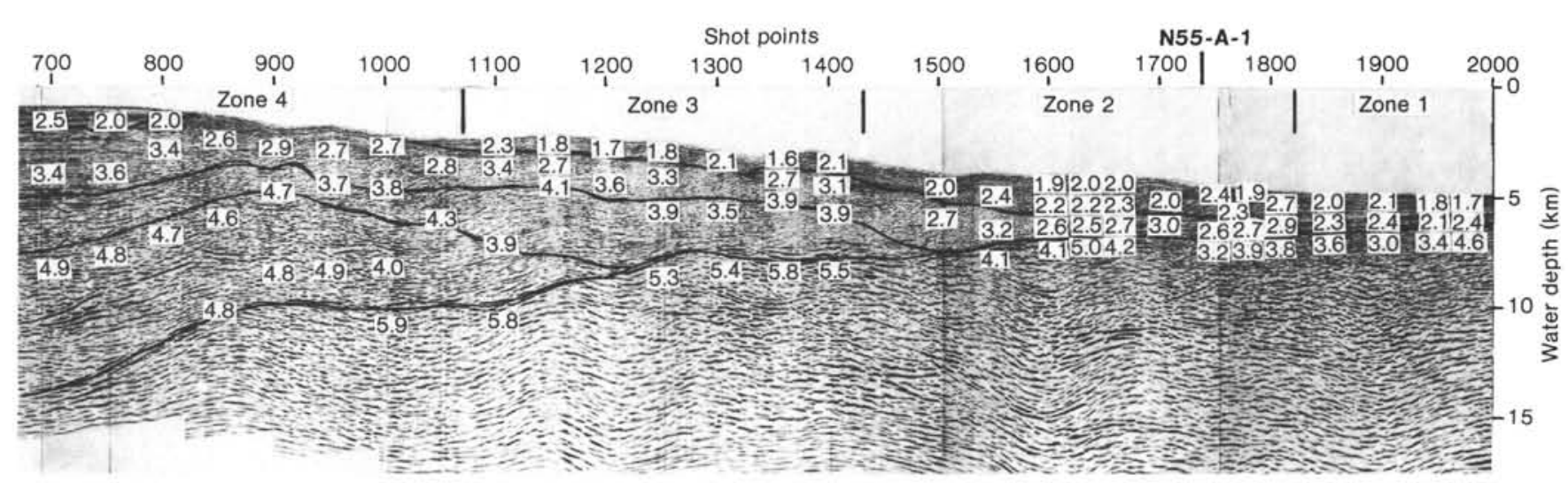

Figure 12. Velocity distribution (in km/s) of the accretionary prism along Profile N55-3-1. For location, see Figure 14. 


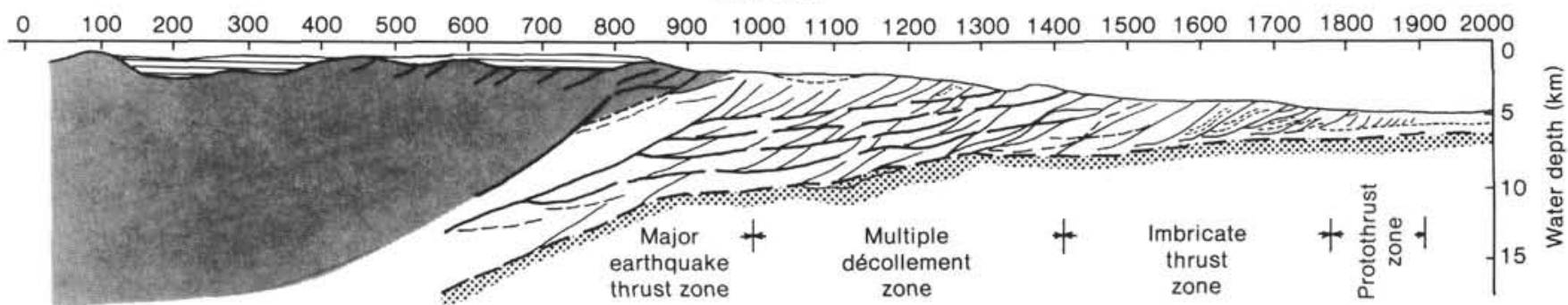

Figure 13. Schematic drawing of the Nankai accretionary prism showing four tectonic zones.

Table 1. Four tectonic zones of the Nankai accretionary prism.

\begin{tabular}{|c|c|c|c|c|}
\hline Zone & $\begin{array}{l}\text { Thickness } \\
\text { (m) }\end{array}$ & $\begin{array}{l}\text { Stácking } \\
\text { velocity } \\
(\mathrm{km} / \mathrm{s})\end{array}$ & $\begin{array}{l}\text { Types of thrust and } \\
\text { other features }\end{array}$ & $\begin{array}{c}\text { Thickening } \\
\text { ratio } \\
(\mathrm{m} / \mathrm{km})\end{array}$ \\
\hline Protothrust zone & $500-1000$ & $\begin{array}{l}1.7-2.1 \\
2.1-2.4\end{array}$ & $\begin{array}{l}\text { Box folding, } 60^{\circ} \text { thrusts, } \\
\text { and incipient décollement }\end{array}$ & 50 \\
\hline $\begin{array}{l}\text { Imbricate (or duplex) } \\
\text { thrust zone }\end{array}$ & $1800-3000$ & $\begin{array}{l}1.9-2.4 \\
2.5-3.2\end{array}$ & $\begin{array}{l}30-40^{\circ} \text { thrusts and } \\
\text { primary décollement }\end{array}$ & 65 \\
\hline $\begin{array}{l}\text { Multiple décollement } \\
\text { zone }\end{array}$ & $3500-5000$ & $\begin{array}{l}1.6-2.1 \\
2.7-3.4 \\
3.5-3.9\end{array}$ & $\begin{array}{l}\text { Thrusts, folding, and } \\
\text { multiple décollements }\end{array}$ & 100 \\
\hline Earthquake thrust zone & $5500-7000$ & $\begin{array}{l}2.6-2.9 \\
3.7-3.8 \\
4.0-4.9\end{array}$ & $\begin{array}{l}\text { Seismic thrusts } \\
\text { (1946 Nankaido thrust) }\end{array}$ & 120 \\
\hline
\end{tabular}

the thrusts, which are particularly prominent in the west. The base of the imbricate blocks is bounded by a primary décollement to which each thrust converges and deepens the level landward. This is perhaps a manifestation of the underplating process proposed by Moore and others (1982). In some profiles, particularly in the eastern part of the studied area, duplex thrusts and imbricate thrusts without rotation of the imbricate slices are observed. This transitional area where duplex thrusts develop is characterized by embayment in zonal arrangement (Fig. 14). Because duplex thrusts are effective means of horizontal transport of sediments, they can accumulate stress under the continental slope faster than other areas. This may be the reason why great historical earthquakes occurred in this area.

The average thickening ratio of the zone is $65 \mathrm{~m} / \mathrm{km}$ (Table 1), meaning the total thickness gains $65 \mathrm{~m}$ for a horizontal distance of $1 \mathrm{~km}$. Drilling results at Site 583 indicate that vertical displacement along the first major imbricate thrust is approximately $150 \mathrm{~m}$ (Seismic Stratigraphy section, site chapter, Site 583, this volume), and the average width of the imbricate blocks is about $3 \mathrm{~km}$. Using these values, we estimate the contribution of the major imbricate thrust of thickening of the wedge to be 30 to $40 \%$. The rest of the thickening is attributed to underplating $(40 \%)$ and to microfaulting $(20 \%)$, using the data of Kagami and others (1982). In the landward imbricate blocks, however, thickening is almost entirely attributable to rotation of the imbricate slices.

The velocity of Zone 2 is fairly constant, ranging between 2.5 and $3.2 \mathrm{~km} / \mathrm{s}$. From the table of sonic log-de- rived porosity (Schlumberger, 1972), the porosity of wedge sediments in this zone is estimated to be 30 to $50 \%$. Sediments with porosities over $30 \%$ can easily deform at high pore water pressure within the strata, producing a variety of deformation.

The third zone is the major accreted or multiple décollement zone. This zone is, in some aspects, similar to the flysch nappe of the Ultra-dauphines Zone in the French Alps but differs in its very low sediment velocity. High-angle bedding (thrusts) in the lower horizon of the landward side gradually decrease and flatten seaward into multiple slip planes. Bedding is highly folded in the upper horizon in the landward side (e.g., Profile 55-8: Tamano et al., 1983). These features are quite similar to the Alpine nappes. The thickening ratio becomes very high in this zone (Table 1), a result of a combination of major thrusting and multiple décollement in the front, steep bedding (thrusts) in the back, and folding in the upper horizon. The velocity of the third zone ranges between 1.6 and $3.9 \mathrm{~km} / \mathrm{s}$. This magnitude and wide range shows that the confining pressure and/or tectonic pressure of the wedge is higher in the deeper landward horizon (Fig. 12), indicating porosities over $20 \%$. This value is almost the limit of plastic deformation and explains the absence of multiple décollements within these deeper landward horizons. Well-developed multiple décollements may cause uplifting of the Minami Muroto Knoll, one of the most prominent culminations within the multiple décollement zone (Fig. 14).

The primary décollements are formed by overburden of the trench-fill sediments, which creates high pore-wa- 


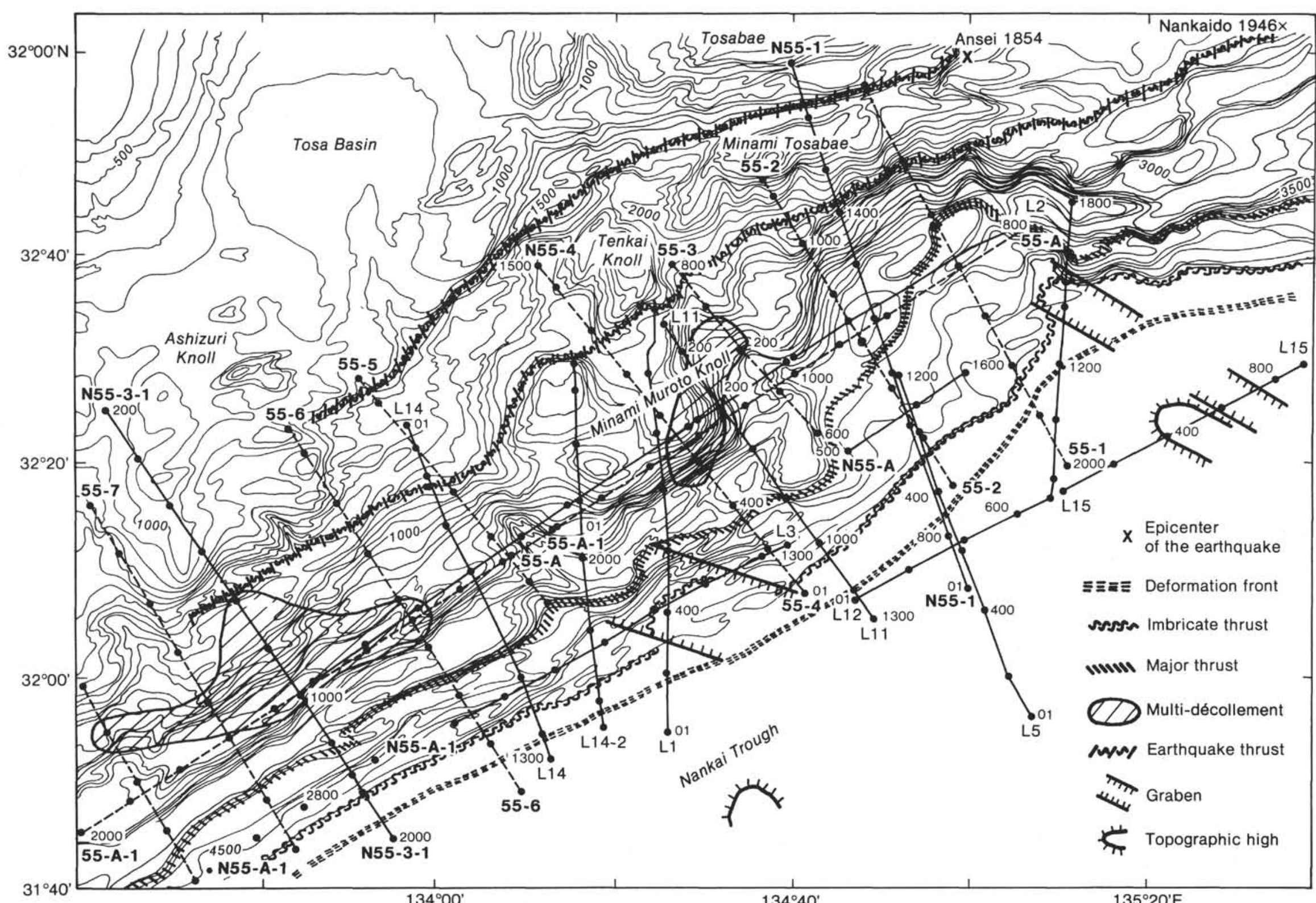

Figure 14. Areal distribution of the four tectonic zones of the Nankai accretionary prism. Contour interval, $100 \mathrm{~m}$. 
ter pressure at a porosity range of 30 to $50 \%$ in the hemipelagite and lower turbidite sequence. Multiple décollements develop for special reasons. One possibility is the reactivation of trapped water in the primary décollement. Most of the water disappeared through the splay thrust faults climbing off the basal décollement. However, with increasing confining pressure, the remains of the trapped water may be reactivated. Another possibility is secondary dewatering, which causes relatively high pore-water pressure in the higher confining condition than the primary dewatering. The secondary dewatering is generally formed at around $20 \%$ porosity range by dissolution of sediment grains and matrix, shrinkage cracks, and diagenetic fractures (Schmidt and McDonald, 1979) or by diagenesis of clay sediments. The overburden of 4-kmthick sediments plus tectonic compressional stress may be enough to cause diagenetic change in this horizon.

The fourth zone is called the earthquake thrust zone. Active $\left(\mathrm{T}_{2}\right)$ faulting occurring along the outer margin of the Tosa Terrace is included in this zone. The major lowangle thrust dips landward at an angle of 10 to $15^{\circ}$ under the Tosa Terrace and marks the Wadachi-Benioff plane under the Shikoku Island. Velocities within the zone attain 2.6 to $4.9 \mathrm{~km} / \mathrm{s}$, and near the seismic thrust exceed $4.0 \mathrm{~km} / \mathrm{s}$, indicating porosities of less than $20 \%$. Under these conditions, it is natural for elastic rupture to occur.

According to Hatori (1974), large tsunamis have repeatedly occurred at an average interval of 120 yr. For example, Hoei (1707) of magnitude 8.4 occurred at $33^{\circ} 12^{\prime} \mathrm{N}$ and $135^{\circ} 53^{\prime} \mathrm{E}$, Ansei (1854) of magnitude 8.4 at $33^{\circ} 00^{\prime} \mathrm{N}$ and $134^{\circ} 51^{\prime} \mathrm{E}$, and Nankaido (1946) of magnitude 8.1 at $33^{\circ} 02^{\prime} \mathrm{N}$ and $135^{\circ} 33^{\prime} \mathrm{E}$. Based on arrival time at coasts, the source areas of tsunamis are estimated to have lengths of 250 to $300 \mathrm{~km}$, dips of 10 to $20^{\circ}$, and dip slips of 4 to $6 \mathrm{~m}$ (Ando, 1975). For each 120 -yr. interval, the vertical uplift at the seismic thrust is estimated to be 70 to $200 \mathrm{~cm}$. Because the landward block of the seismic thrust is composed of the accreted sediments, the vertical uplift of 70 to $200 \mathrm{~cm}$ every 120 yrs. may contribute absolute accretion to the Nankai wedge. Also, historically, epicenters seem to migrate seaward with time, and this progression may contribute to further sediment accretion.

\section{ACKNOWLEDGMENTS}

The author would like to express his gratitude to Professor Noriyuki Nasu, chairman of the Japanese IPOD committee, for his encouragement during this study. Discussions with Dr. Asahiko Taira were also quite helpful. The author is also greatly indebted to Professor Jean Aubouin for an excursion through the French Alps in 1984 and for the comparison of Alpine nappe tectonics with modern accretionary wedges. Data on the air-gun survey and bathymetry were kindly arranged by Drs. Takahiro Sato and Misao Sakurai of the Hydrographic Depart- ment of Japan. This report was kindly reviewed by Dr. William Coulbourn of the Hawaii Institute of Geophysics, and Ms. Elizabeth Whalen of DSDP, Scripps Institution of Oceanography,

\section{REFERENCES}

Ando, M., 1975. Source mechanisms and tectonic significance of historical earthquakes along the Nankai Trough, Japan. Tectonophysics, 27:119-140.

Aoki, Y., Tamano, T., and Kato, S., 1982. Detailed structure of the Nankai Trough from migrated seismic sections. Am. Assoc. Pet. Geol. Mem., 34:309-322.

Bally, A. W., and Snelson, S., 1980. Facts and principles of world petroleum occurrence: realms of subsidence. Can. Soc. Pet. Geol. Mem., 6:9-94.

Boyer, S. E., and Elliott, D., 1982. Thrust systems. Am. Assoc. Pet. Geol. Bull., 66:1196-1230.

Hatori, T., 1974. Source of large Tsunamis in southwest Japan. Zisin, 27:10-24.

Inoue, E. (Ed.), 1978. Investigations of the Continental Margin of Southwest Japan: Tsukuba (Geological Survey of Japan), Cruise Report No. 9.

Kagami, H. (Ed.), 1975. Preliminary Report of the Hakuho Maru Cruise KH72-2: Tokyo (Ocean Research Institute, University of Tokyo).

Kagami, H., Tokuyama, H., Kong, Y. S., Igarashi, C., and Nasu, N., 1982. Multichannel seismic reflection survey in the Nankai Trough off Ashizuri, southwest Japan. Kaiyo-Kagaku, 14:351-357.

Kagami, H., Shiono, S., and Taira, A., 1983. Plate subduction and formation of the accretionary prism along the Nankai Trough. Kagaku, 53:429-438.

Kagami, H., Tokuyama, H., and Nishiyama, A., 1985. Structure of the Nankai accretionary prism, In Kajiura, K. (Ed.), The Ocean Characteristics and their Changes: Tokyo (Koseisha-Koseikaku), pp. 287-296.

Moore, J. C., and Watkins, J. S., Shipley, T. H., McMillen, K. J., Bachman, S. B., and Lundberg, N., 1982. Geology and tectonic evolution of a juvenile accretionary terrane along a truncated convergent margin: synthesis of results from Leg 66 of DSDP. Geol. Soc. Am. Bull., 93:847-861.

Nasu, N., Tomoda, Y., Kobayashi, K., Kagami, H., et al., 1982. Multichannel Seismic Reflection Data Across Nankai Trough: Tokyo (Ocean Research Institute, University of Tokyo), IPOD-Japan Basic Data Series, No. 4.

Okuda, Y., 1984. Tectonic evolution of the continental margin off southwest Japan during the late Cenozoic. Rep. Tech. Res. Cent. JNOC, 19:33-93.

Research Group For Active Faults, 1980. Active Faults In Japan: Tokyo, (University of Tokyo Press).

Schlumberger, 1972. Log Interpretation Charts: New York, (Schlumberger Limited).

Schmidt, V., and McDonald, D. A., 1979. Secondary Reservoir Porosity in the Course of Sandstone Diagenesis: Tulsa, Oklahoma (Am. Assoc. Pet. Geol.), Continuing Education Course Note, Ser. 12.

Tamano, T., Toba, Y., and Aoki, Y., 1983. Development of forearc continental margins and their potential for hydrocarbon accumulation. Pet. Geol., PD3:1-11.

Yoshii, T., Ludwig, W. J., Den, N., Murauchi, S., Ewing, M., Hotta, H., Buhl, P., Asanuma, T., and Sakajiri, N., 1973. Structure of southwest Japan margin off Shikoku. J. Geophys. Res., 78: $2517-2525$.

Date of Initial Receipt: 9 July 1984

Date of Acceptance: 25 January 1985 